\title{
Lilium longiflorum Plant Growth with a combination of Naphthylacetic Acid (NAA) and 6- Benzylaminopurine (BAP) In Vitro
}

Rosita Husnun Fauziah ${ }^{1 *}$, Florentina Kusmiyati), Syaiful Anwar ${ }^{3)}$

Agroecotechnology, Faculty of Animal and Agricultural Sciences, Diponegoro University

Tembalang Campus, Semarang 50275 - Indonesia

*)Corresponding Author: rositafauziah35@gmail.com

\section{ABSTRACT}

This research was aim to identify the effect of Naphthylacetic Acid (NAA) and 6Benzylaminopurin (BAP) on the growth of Lilium longiflorum planlet. The research method was Completely Randomized Design Factorial $4 \times 4$ with 4 replication. First factor was concentration of NAA, consist of A0: $0 \mathrm{mg} / \mathrm{l}, \mathrm{A1}: 0,75 \mathrm{mg} / \mathrm{l}, \mathrm{A} 2: 1,5 \mathrm{mg} / \mathrm{l}$, and A3: 2,25 mg/l. Second factor was concentration of BAP, consist of : B0: $0 \mathrm{mg} / \mathrm{l}, \mathrm{B} 1: 0,3 \mathrm{mg} / \mathrm{l}, \mathrm{B} 2: 0,6 \mathrm{mg} / \mathrm{l}$, and B3: 0,9 mg/l. The observed parameters were the number of shoots, plant height, number of leaves, number of roots, and percentage of contamination. Data were processed by Analysis of Variance and continued by Least Significance Different (LSD). The result showed that combination of NAA and BAP did not significantly affect the growth parameter of Lilium longiflorum. BAP treatment significantly affected the number of shoots and number of leaves. The number of roots only observed in NAA treatment; 0,3 mg/l BAP + 0,75 mg/l NAA; 0,3 mg/l BAP + 1,5 mg/l NAA; and 0,6 mg/l BAP + $0,75 \mathrm{mg} / \mathrm{l}$ NAA. Percentage of fungal contamination was $7,5 \%$. The conclusion of the result was the treatment of $0,3 \mathrm{mg} / \mathrm{l} \mathrm{BAP}+0,75 \mathrm{mg} / \mathrm{NAA}$ was the best treatment for growth of Lilium longiflorum planets with no contamination.

Keyword: Lilium longiflorum, $N A A, B A P$, in vitro

\section{PENDAHULUAN}

Lili (Lilium Longiflorum) merupakan tanaman herba berumbi yang termasuk tanaman perennial atau tahunan. Tanaman lili berasal dari negara-negara yang memiliki iklim sedang antara lain Eropa, Jepang, dan Amerika Utara. Tanaman lili pada umumnya dapat tumbuh baik di tempat yang memperoleh sinar matahari sekitar 5-6 jam per hari. Budidaya tanaman lili di Indonesia terletak di daerah-daerah dataran rendah sampai dataran tinggi dengan ketinggian 300-1200 mdpl. Perbanyakan tanaman lili di Indonesia bertujuan sebagai bunga potong. Umumnya di Indonesia sendiri perbanyakan lili masih dilakukan secara konvensional menggunakan umbi. Perbanyakan menggunakan umbi membutuhkan waktu yang relatif lama sekitar 3-5 tahun, karena umbi mengalami masa dormansi, sehingga tidak dapat langsung digunakan sebagai bibit. Oleh karena itu, perlu adanya teknik perbanyakan lili secara in vitro atau biasa disebut dengan kultur jaringan untuk mendapatkan bibit dalam jumlah besar dan dalam waktu yang relatif singkat.

Perbanyakan tanaman secara in vitro yaitu memperbanyak tanaman menggunakan bagian-bagian tanaman seperti jaringan, sel dan organ yang 
dikulturkan dalam media buatan yang kaya akan sumber nutrisi dan zat pengatur tumbuh (ZPT) serta dalam kondisi yang aseptik sehingga tanaman dapat memperbanyak diri dan beregenerasi menjadi tanaman lengkap (Tajuddin et al., 2012). Media yang digunakan dalam perbanyakan tanaman secara in vitro ada beberapa jenis, salah satunya yaitu Murashige and Skoog (MS), media ini terdiri dari unsur hara makro, mikro, zat besi, vitamin, serta dilengkapi dengan zat pengatur tumbuh (ZPT) guna menunjang pertumbuhan eksplan. Keberhasilan perbanyakan tanaman secara in vitro dipengaruhi oleh beberapa faktor antara lain media yang digunakan, jenis eksplan, dan zat pengatur tumbuh.

Penggunaan zat pengatur tumbuh (ZPT) dalam kultur in vitro merupakan salah satu faktor yang menunjang keberhasilan kultur in vitro suatu tanaman. Zat pengatur tumbuh merupakan senyawa organik yang aktif dalam konsentrasi rendah serta berperan dalam merangsang atau menghambat tumbuh dan kembang suatu tanaman baik secara kuantitatif maupun kualitatif (Lawalata, 2011). Zat pengatur tumbuh (ZPT) yang digunakan dalam perbanyakan tanaman secara in vitro yaitu ZPT auksin dan sitokinin. Auksin berperan dalam meningkatkan sintesis protein dan meningkatkan plastisitas serta pengembangan dinding sel sehingga membantu penyerapan nutrisi dalam media kultur (Karjadi dan Buchory, 2007). Auksin juga berperan dalam menginduksi proses pembelahan dan differensiasi sel untuk berubah menjadi perakaran (Yuniati et al., 2018). Auksin sintetik yang biasa digunakan dalam perbanyakan lili secara in vitro yaitu Naphthylacetic acid (NAA). Konsentrasi NAA dalam media kultur yang relatif tinggi dapat menginduksi pembentukan akar pada Lilium sp. (Hoesen, 2009).

Selain zat pengatur tumbuh auksin, dalam keberhasilan teknik kultur in vitro juga dipengaruhi oleh zat pengatur tumbuh sitokinin. Penggunaan sitokinin dalam kultur in vitro berperan meningkatkan laju sintesis protein sehingga mendorong dalam pembesaran dan pembelahan sel (Rosyidah et al., 2014). Penambahan sitokinin pada media kultur jaringan berperan dalam mendorong aktifitas sel dan jaringan eksplan umbi lili sehingga akan memacu pembentukan tunas (Hoesen, 2009). Sitokinin sintetik yang biasa digunkaan yaitu kinetin, dan Benzyl Amino Purine (BAP). BAP merupakan sitokinin yang paling efektif untuk multiplikasi tunas pada Lilium (Aslam et.al., 2013). Pemberian BAP $1 \mathrm{mg} / \mathrm{l}$ mampu menghasilkan 7,67 tunas dan 10,67 daun pada Lilium sp. (Hoesen, 2009).

Kombinasi antara auksin dan sitokinin dengan konsentrasi yang sesuai dapat 
menentukan keberhasilan multiplikasi bulblet secara in vitro. Setiap tanaman memiliki kisaran kebutuhan ZPT yang berbeda-beda, begitu pula untuk multiplikasi bulblet tanaman lili. Penelitian sebelumnya yang telah dilakukan oleh Skoric et al. (2012) Lilium martagon yang di multiplikasikan pada media 0,2 mg/l BAP + 0,25 mg/l NAA dihasilkan pembentukan planlet terbaik setelah 6 minggu kultur. Pandey et al. (2009) menunjukkan bahwa pemberian $0,27 \mathrm{mg} / \mathrm{l}$ BAP + 0,5 mg/l NAA pada eksplan umbi (bulbs) tanaman lili dihasilkan presentase poliferasi sebesar $82,62 \%$ dan diperoleh presentase pembentukan akar terbesar yaitu 97\% dengan panjang akar 1,66 cm setelah disbukulturkan pada media dengan $1 \mathrm{mg} / \mathrm{l}$ NAA.

Berdasarkan penelitian yang telah disebutkan mengenai konsentrasi NAA dan BAP pada perbanyakan Lilium secara in vitro, maka perlu dilakukan penelitian kombinasi berbagai konsentrasi NAA dan BAP sebagai upaya untuk pembentukan planlet Lilium longiflorum dari hasil multiplikasi bulblet. Tujuan dari penelitian ini adalah mengkaji pengaruh interaksi hormon NAA dan BAP yang berbeda terhadap pertumbuhan planlet Lilium longiflorum.

\section{METODE PENELITIAN}

Penelitian telah dilaksanakan pada 18 Juli - 18 September 2019 di Laboratorium Fisiologi dan Pemuliaan Tanaman, Fakultas
Peternakan dan Pertanian, dan Laboratorium Tropical Marine Biotechnology, fakultas Perikanan dan IImu Kelautan, Universitas Diponegoro, Semarang.

Penelitian menggunakan Rancangan Acak Lengkap (RAL) faktorial dengan 2 faktor perlakuan $(4 \times 4)$. Faktor pertama adalah konsentrasi NAA, yaitu: A0: $0 \mathrm{mg} / \mathrm{l}$, A1: 0,75 mg/l, A2: 1,5 mg/l, dan A3: 2,25 $\mathrm{mg} / \mathrm{l}$. Faktor kedua adalah konsentrasi BAP, yaitu: B0: 0 mg/l, B1: 0,3 mg/l, B2: 0,6 mg/l, dan B3: 0,9 mg/l. Percobaan diulang sebanyak 4 kali ulangan sehingga diperoleh 64 satuan percobaan.

Pelaksanaan penelitian dilakukan dalam beberapa tahap, antara lain yaitu sterilisasi botol, pembuatan larutan stok, pembuatan media, sterilisasi ruangan, sterilisasi alat tanam, dan multiplikasi planlet. Sterilisasi botol dan alat tanam dilakukan dengan cara dicuci menggunakan detergen dan bayclin, kemudian disterilisasi menggunakan oven dengan suhu $125^{\circ} \mathrm{C}$ selama 2 jam.

Pembuatan larutan stok dimulai dengan menimbang hara makro, hara mikro, zat besi, vitamin, dan myoinositol sesuai komposisi media MS (Murashige dan Skoog) untuk dibuat larutan stok (Tabel 1).

Bahan-bahan tersebut dilarutkan dengan akuades sesuai dengan kebutuhan. Larutan diaduk menggunakan magnetic 
stirer sampai larutan homogen. Larutan ditera sesuai dengan volume masingmasing. Pembuatan larutan stok ZPT 100 ppm diawali dengan menimbang NAA dan BAP sejumlah 0,01 g/100 ml. Selanjutnya BAP dan NAA dilarutkan dengan $\mathrm{NaOH} 1 \mathrm{~N}$,

Tabel 1. Komposisi Media Murashige and Skoog (MS)

\begin{tabular}{|c|c|c|c|}
\hline No. & Komposisi & $\begin{array}{l}\text { Konsentrasi dalam } \\
\text { media MS (g/l) }\end{array}$ & $\begin{array}{c}\text { Konsentrasi dalam stok } \\
\text { (g/Volume) }\end{array}$ \\
\hline & & $1 \times$ konsentrasi & $20 \times$ konsentrasi \\
\hline 1. & $\mathrm{KNO}_{3}$ & 1,9 & 38 \\
\hline 2. & $\mathrm{NH}_{4} \mathrm{NO}_{3}$ & 1,65 & 33 \\
\hline 3. & $\mathrm{CaCl}_{2} .2 \mathrm{H}_{2} \mathrm{O}$ & 0,44 & 8,8 \\
\hline 4. & $\mathrm{MgSO}_{4} .7 \mathrm{H}_{2} \mathrm{O}$ & 0,37 & 7,4 \\
\hline \multirow[t]{2}{*}{5.} & $\mathrm{KH}_{2} \mathrm{PO}_{4}$ & 0,17 & 3,4 \\
\hline & & $1 \times$ konsentrasi & $100 \times$ konsentrasi \\
\hline 6. & $\mathrm{H}_{3} \mathrm{BO}_{3}$ & 0,0062 & 0,031 \\
\hline 7. & $\mathrm{MnSO}_{4} .4 \mathrm{H}_{2} \mathrm{O}$ & 0.0169 & 1.69 \\
\hline 8. & $\mathrm{ZnSO}_{4.7} \mathrm{H}_{2} \mathrm{O} \mathrm{H}_{3} \mathrm{BO}_{3}$ & 0,0086 & 0,86 \\
\hline 9. & $\mathrm{Na} \mathrm{MoO}_{4} .2 \mathrm{H}_{2} \mathrm{O}$ & 0,00025 & 0,025 \\
\hline 10. & $\mathrm{CuSO}_{4} .5 \mathrm{H}_{2} \mathrm{O}$ & 0,000025 & 0,0025 \\
\hline 11. & $\mathrm{CaCl}_{2} .6 \mathrm{H}_{2} \mathrm{O}$ & 0,000025 & 0,0025 \\
\hline \multirow[t]{2}{*}{12.} & $\mathrm{KI}$ & 0,00083 & 0,083 \\
\hline & & $1 \times$ konsentrasi & $100 \times$ konsentrasi \\
\hline 13. & $\mathrm{FeSO}_{4} .7 \mathrm{H}_{2} \mathrm{O}$ & 0,02785 & 2,785 \\
\hline \multirow[t]{2}{*}{14.} & $\mathrm{Na}_{2}$ EDTA. $2 \mathrm{H}_{2} \mathrm{O}$ & 0,03725 & 3,725 \\
\hline & & $1 \times$ konsentrasi & $1000 \times$ konsentrasi \\
\hline 15. & Thiamin & 0,0001 & 0,1 \\
\hline 16. & Piridoksin $\mathrm{HCl}$ & 0,0005 & 0,5 \\
\hline 17. & Nicotinic acid & 0.0005 & 0.5 \\
\hline 18. & Myoinositol 100x (take $1 \mathrm{ml} / \mathrm{l}$ ) & 0,01 & 10 \\
\hline
\end{tabular}

Pembuatan media dimulai dengan memasukkan larutan stok MS yang telah dibuat dan stok hormon NAA dan BAP sesuai konsentrasi ke dalam erlenmeyer, kemudian ditambahkan akuades. Media ditambah gula pasir $30 \mathrm{~g} / \mathrm{l}$ dan diukur keasaman larutan menggunakan $\mathrm{pH}$ meter sampai $\mathrm{pH}$ larutan menjadi 5,8. Apabila $\mathrm{pH}$ terlalu asam maka ditambah $\mathrm{NaOH} 0,1 \mathrm{~N}$ kemudian ditambah akuades dan ditera dengan akuades sampai volume larutan 100 ml. Larutan dimasukkan ke dalam botol yang telah diberi label kemudian disimpan di kulkas. 
dan direkatkan dengan karet gelang. Kemudian media disterilisasikan menggunakan autoclave pada suhu $121^{\circ} \mathrm{C}$ dan tekanan 1,75 atm selama 20 menit. Media kemudian diletakkan di rak kultur.

Multiplikasi dimulai dengan eksplan planlet lili dikeluarkan dari botol kultur, bahan eksplan yang berupa bulblet dibersihkan dari akar dan daun. Bulblet yang telah dipotong direndam dengan alkohol $70 \%$ selama 3 menit, kemudian direndam dengan akuades steril selama 3 menit dan ditiriskan di atas kertas saring. Eksplan yang telah disteriliasi diinisiasi pada botol kultur yang berisi media. Satu botol berisi satu bulblet lili. Kultur ditempatkan di ruang terang dengan suhu 20 $\pm 1^{\circ} \mathrm{C}$.

Pengambilan data dilakukan satu minggu sekali setelah inisiasi eksplan. Parameter yang diamati adalah jumlah tunas, tinggi planlet, jumlah daun, jumlah akar, dan persentase kontaminasi. Data jumlah tunas, tinggi planlet, jumlah daun yang diperoleh dianalisis menggunakan analisis ragam dengan taraf $5 \%$. Apabila terdapat beda nyata antar perlakuan dan taraf perlakuan maka dilanjutkan menggunakan uji Beda Nyata Terkecil (BNT) pada taraf $5 \%$. Data jumlah akar dan persentase kontaminasi di analisis secara deskriptif.

\section{HASIL DAN PEMBAHASAN} Jumlah Tunas
Data jumlah tunas pada Tabel 2. Pemberian perlakuan BAP pada berbagai taraf konsentrasi bepengaruh nyata terhadap jumlah tunas. Pemberian perlakuan BAP $0,9 \mathrm{mg} / \mathrm{l}$ memberikan ratarata jumlah tunas terbanyak yaitu 1,81 \pm 0,19 tunas dibandingkan dengan perlakuan BAP $0 \mathrm{mg} / \mathrm{l}, 0,3 \mathrm{mg} / \mathrm{l}$ dan $0,6 \mathrm{mg} / \mathrm{l}$ yang menghasilkan rata-rata jumlah tunas 1,25 \pm $0,18,1,25 \pm 0,10,1,25 \pm 0,31$ tunas. Hal tersebut menunjukkan bahwa pemberian sitokinin BAP pada berbagai taraf efektif untuk merangsang multiplikasi tunas pada Lilium longiflorum secara in vitro dilihat dari tunas yang tumbuh disetiap perlakuan.

Hal ini sesuai dengan fungsi sitokinin yaitu berperan dalam mendorong aktifitas sel dan jaringan pada umbi lili yang dilukai melalui peningkatan laju sintesis protein, protein yang terbentuk tersebut antara lain berupa enzim yang berperan dalam pembelahan sel, sehingga dengan penambahan sitokinin eksogen atau BAP akan memacu pembentukan tunas. Menurut Aslam et al. (2013) BAP merupakan sitokinin yang paling efektif untuk multiplikasi tunas pada Lilium . Sun et al. (2013) menambahkan bahwa pemberian BAP pada konsentrasi yang tinggi akan meningkatkan jumlah tunas pada Liliceae. Hal tersebut juga sesuai dengan penelitian ini, jumlah tunas terbanyak dihasilkan oleh penambahan BAP dengan konsentrasi paling tinggi $0,9 \mathrm{mg} / \mathrm{l}$. 
Tabel 2. Jumlah Tunas Berdasarkan Kombinasi NAA dan BAP

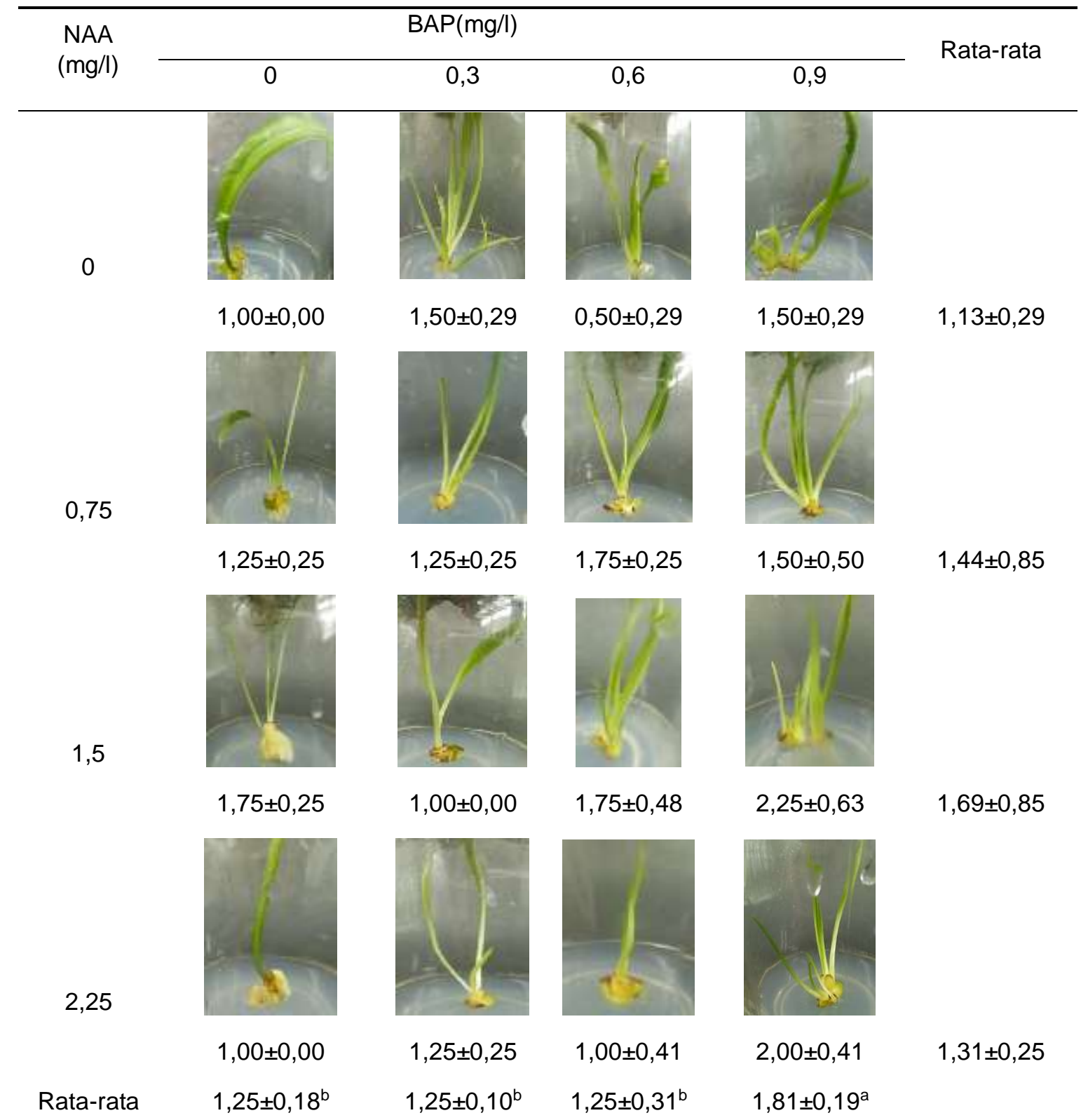

Superskrip berbeda menunjukkan perbedaan nyata $(p<0,05)$ diikuti oleh " \pm " sebagai tanda standar eror.

Interaksi berbagai taraf konsentrasi NAA dan BAP pada penelitian ini tidak memberikan pengaruh yang nyata terhadap jumlah tunas (Tabel 2). Hal tersebut tidak sesuai dengan penelitian sebelumnya Mir et al. (2012) bahwa interaksi NAA dan BAP pada multiplikasi Lilium Iongiflorum berpengaruh nyata terhadap jumlah tunas setelah 4 minggu kultur. Interaksi antara BAP dan NAA pada penelitian ini tidak berpengaruh nyata terhadap jumlah tunas diduga karena taraf konsentrasi NAA dan 
BAP belum optimal untuk meningkatkan jumlah tunas. Pemberian hormon eksogen NAA dan BAP belum mampu mendorong kerja hormon endogen dalam eksplan sehingga pembelahan dan pembesaran sel belum terjadi secara optimal, akibatnya tunas yang dihasilkan hanya sedikit. Berdasarkan data deskriptif dan kualitatif jumlah tunas selama 6 minggu dapat dilihat bahwa perlakuan 1,5 mg/l NAA + 0,9 mg/l BAP menghasilkan rata-rata jumlah tunas lebih bayak dari perlakuan lain yaitu 2,25 \pm 0,63 tunas. Jumlah tunas pada penelitian ini lebih rendah dari penelitian Hoesen (2009) dimana hasil multiplikasi Lilium sp. pada kombinasi BA (0,5-1 mg/l) dan NAA (0-0,5 $\mathrm{mg} / \mathrm{l})$ jumlah tunas terbanyak dihasilkan oleh perlakuan $0 \mathrm{mg} / \mathrm{l} \mathrm{NAA}+1 \mathrm{mg} / \mathrm{l} \mathrm{BA}$ dengan 6,67 tunas setelah 6 minggu kultur.

\section{Tinggi Planlet}

Rata-rata parameter tinggi planlet lili (Lilium longiflorum) secara in vitro (Tabel 3) menunjukkan bahwa tidak terdapat interaksi antara kedua perlakuan NAA dan BAP, serta semua perlakuan tunggal tidak memberikan pengaruh yang nyata. Hal tersebut tidak sesuai dengan penelitian sebelumnya Skoric et al. (2012) bahwa interaksi antara NAA dan BAP memberikan pengaruh nyata terhadap tinggi planlet pada muliplikasi Lilium martagon setelah 6 minggu kultur. Tidak adanya pengaruh nyata dari kedua perlakuan terhadap tinggi planlet menunjukkan bahwa kombinasi berbagai taraf konsentrasi NAA dan BAP yang digunakan belum pada taraf yang optimal. Tinggi planlet tidak menunjukkan pertumbuhan yang signifikan diduga karena konsentrasi BAP terlalu rendah dan kandungan sitokinin endogen dalam lili juga rendah sehingga ketika dilakukan penambahan akusin eksogen pembelahan dan pemanjangan sel tidak terjadi secara maksimal. Hal tersebut sesuai dengan pendapat Rufaida et al. (2013) bahwa pertumbuhan dan perkembangan planlet dipengaruhi oleh interaksi dan keseimbangan yang optimal antara konsentrasi hormon endogen pada eksplan dan pemberian hormon eksogen.

Data tinggi planlet setelah 6 minggu multiplikasi (Tabel 3) menunjukkan perlakuan 0,75 mg/l NAA + 0,6 mg/l BAP merupakan planlet tertinggi dari perlakuan lain yaitu $8,18 \pm 1,02 \mathrm{~cm}$. Tinggi planlet pada penelitian ini lebih rendah dari penelitian Hoesen (2009) dimana perlakuan 0,5 mg/l $\mathrm{NAA}+1 \mathrm{mg} / \mathrm{BAP}$ dihasilkan tinggi planlet tertinggi yaitu $12,10 \mathrm{~cm}$ selama 6 minggu setelah multiplikasi. Rendahnya tinggi planlet pada penelitian ini diduga karena konsentrasi NAA yang dikombinasikan dengan BAP terlalu tinggi, sehingga pembelahan dan pemanjangan sel akan terhambat dan berakibat pada terhambatnya pertumbuhan tinggi planlet. Hal tersebut 
sesuai dengan penelitian Bakhshaie et al. (2016) pada planlet calla lily, yaitu konsentrasi NAA yang lebih tinggi dalam media akan mengurangi tinggi planlet. Karjadi dan Buchory (2007) mengatakan auksin dalam konsentrasi yang terlalu tinggi akan menyebabkan konsentrasi etilen yang dihasilkan dalam planlet semakin tinggi, hal tersebut akan menghambat aktivitas auksin dalam pemanjangan sel.

Tabel 3. Tinggi Planlet Berdasarkan Kombinasi NAA dan BAP

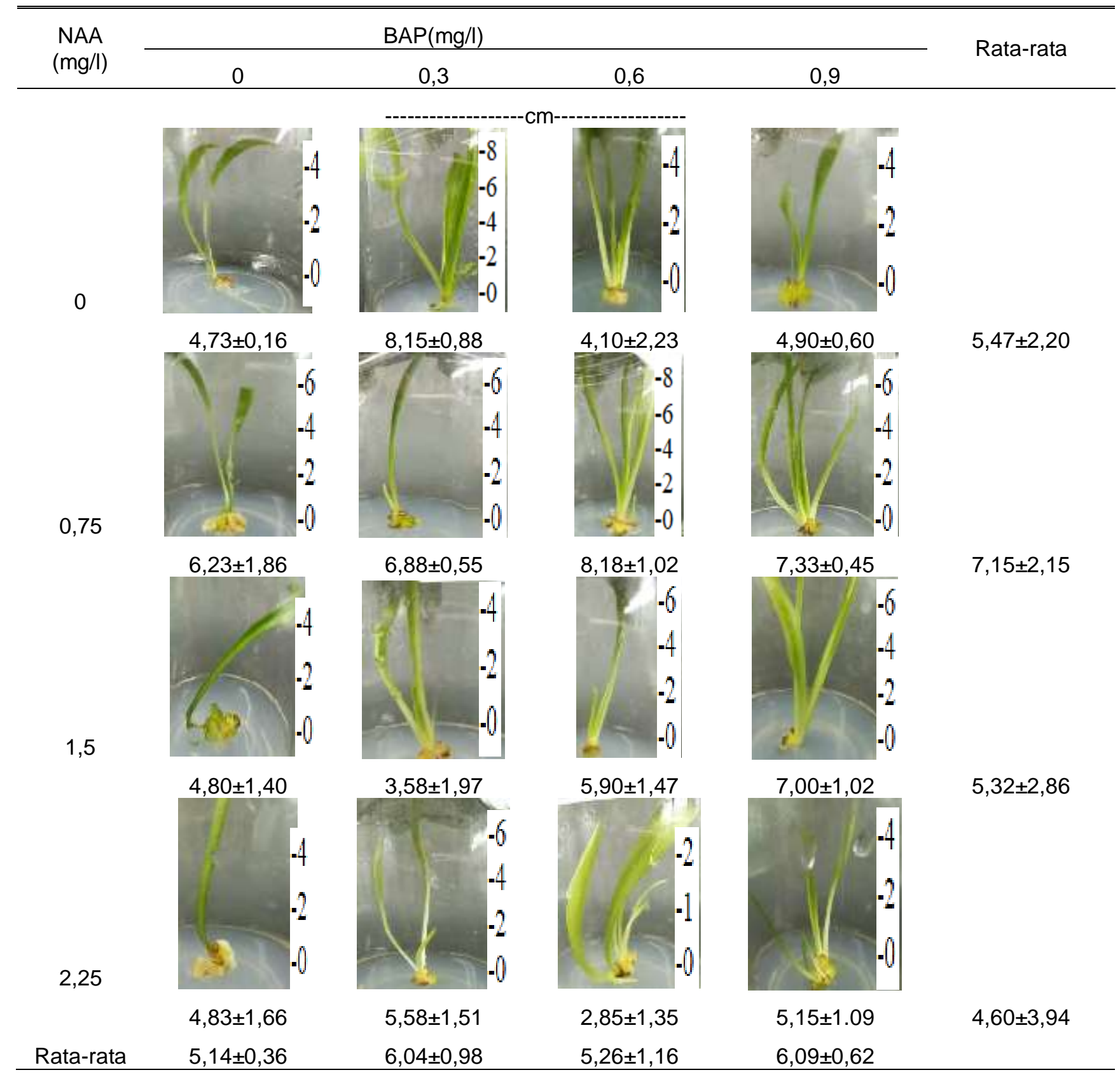




\section{Jumlah Daun}

Jumlah daun semakin bertambah seiring dengan bertambahnya jumlah tunas. Setiap tunas tersebut akan muncul bakal daun yang nantinya akan terbentuk daun. Tunas ke-1 terdapat 3 daun dan tunas ke-2 terdapat 3 daun (llustrasi 1). Hal tersebut sesuai dengan pendapat Wulandari et al. (2018) bahwa banyaknya tunas yang bermultiplikasi, maka jumlah daun yang dihasilkan juga semakin banyak.

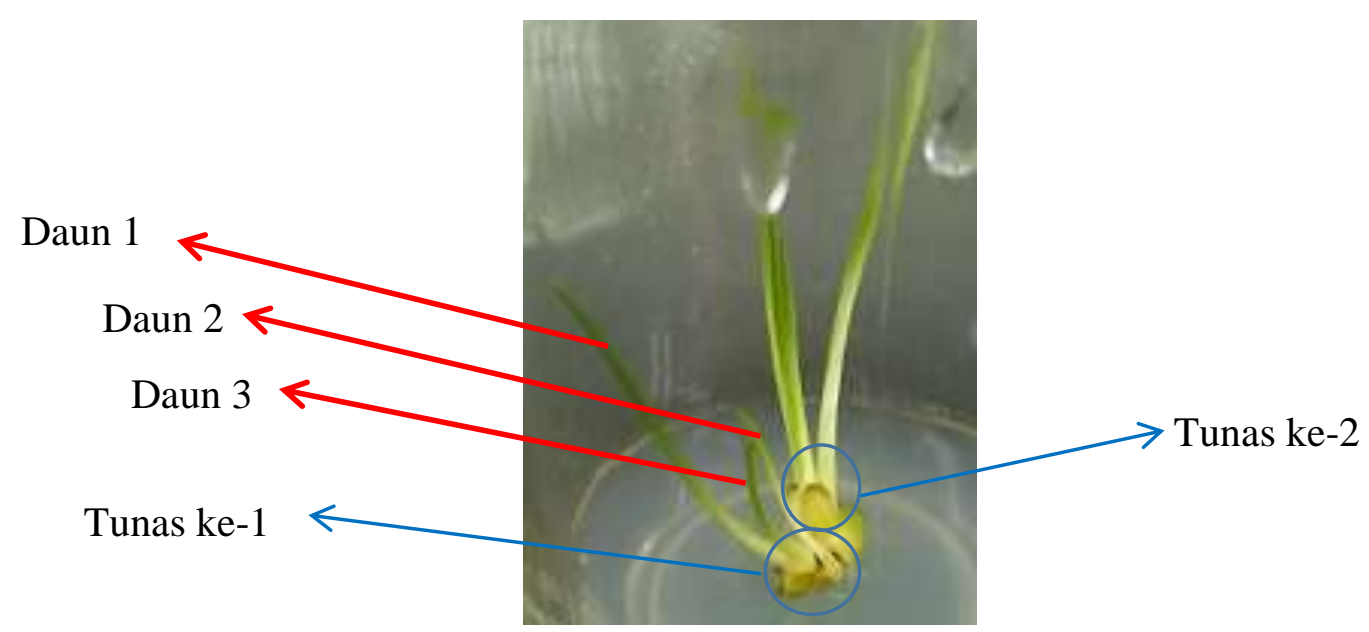

Ilustrasi 1. Jumlah Daun Lilium longiflorum

Data jumlah daun lili (Lilium longiflorum) secara in vitro disajikan pada Tabel 4. Pemberian perlakuan BAP pada berbagai taraf konsentrasi bepengaruh nyata terhadap jumlah daun. Pemberian BAP 0,9 $\mathrm{mg} / \mathrm{l}$ memberikan pengaruh yang berbeda nyata dengan pemberian BAP $0,3 \mathrm{mg} / \mathrm{l}$ dan $0,6 \mathrm{mg} / \mathrm{l}$ terhadap jumlah daun lili. Pemberian BAP $0,3 \mathrm{mg} / \mathrm{l}$ tidak berbeda nyata dengan pemberian BAP 0,6 $\mathrm{mg} / \mathrm{l}$, tetapi berbeda nyata dengan kontrol BAP $0 \mathrm{mg} / \mathrm{l}$. Pertumbuhan jumlah daun semakin bertambah seiring dengan bertambahnya konsentrasi sitokinin eksogen (BAP) yang ditambahkan dalam media. Hal tersebut sesuai dengan Skoric et al. (2012) pembentukan jumlah daun pada Lilium martagon dipengaruhi oleh konsentrasi sitokinin yang semakin meningkat. Sitokinin berperan dalam menstimulasi pembelahan sel yang akan mempengaruhi pembentukan daun. Jumlah daun terbanyak dihasilkan oleh perlakuan 0,9 mg/l BAP, yaitu 6,31 \pm 0,62 daun. Hal tersebut menunjukkan bahwa 0,9 mg/l BAP merupakan konsentrasi BAP yang optimal untuk pertumbuhan jumlah daun. 
Tabel 4. Jumlah Daun Berdasarkan Kombinasi NAA dan BAP

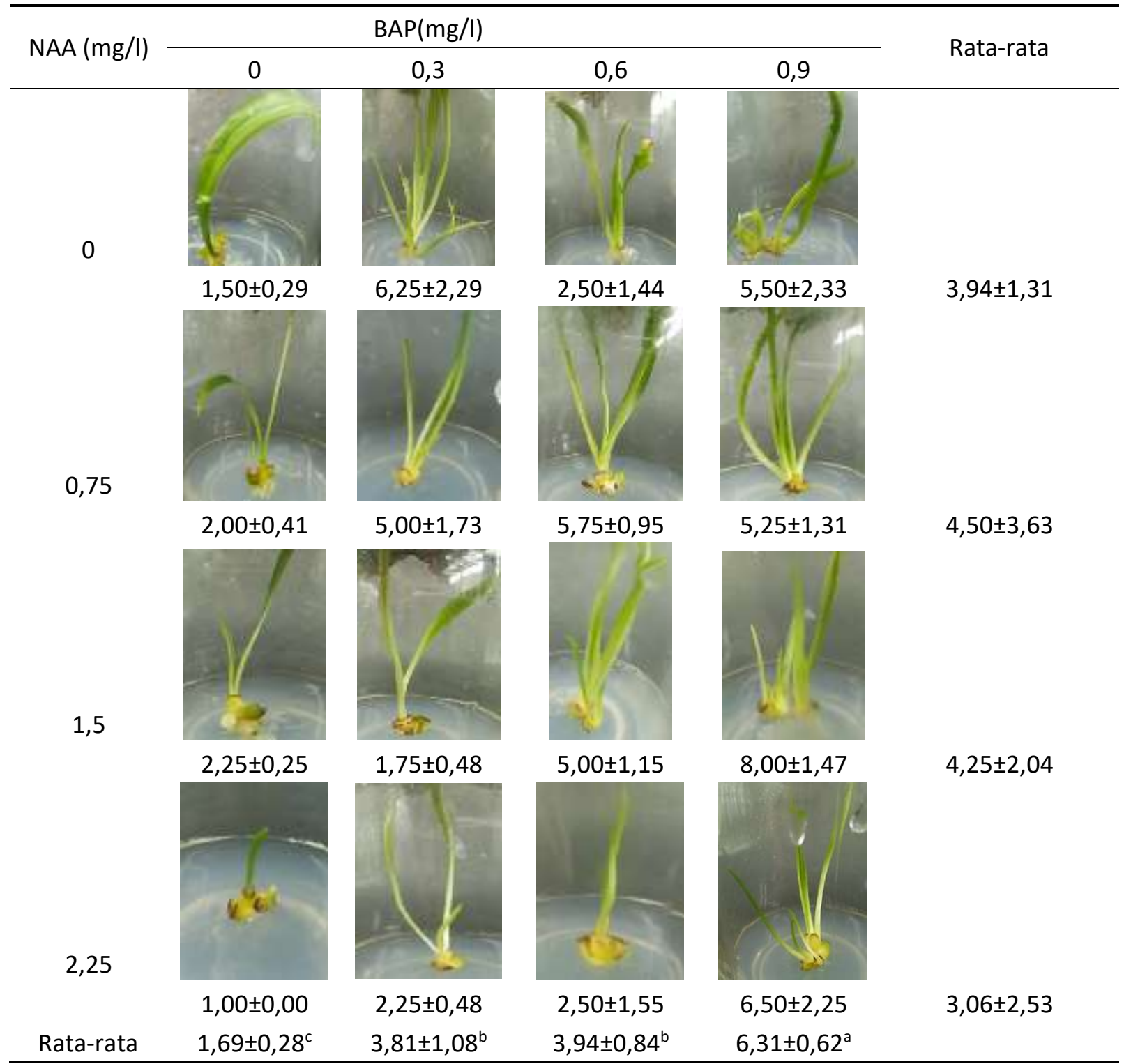

Superskrip berbeda menunjukkan perbedaan nyata $(p<0,05)$ diikuti oleh " \pm " sebagai tanda standar eror.

Pemberian berbagai taraf konsentrasi NAA tidak berpengaruh nyata terhadap jumlah daun Lilium longiflorum. Semakin tinggi konsentrasi NAA maka jumlah daun yang dihasilkan juga semakin sedikit. Perlakuan $0,75 \mathrm{mg} / \mathrm{l}$ NAA menghasilkan jumlah daun $4,50 \pm 3,63$, perlakuan $1,5 \mathrm{mg} / \mathrm{l}$
NAA menghasilkan jumlah daun 4,25 $\pm 2,04$, dan perlakuan 2,25 mg/l NAA menghasilkan jumlah daun $3,06 \pm 2,53$. Hal tersebut menunjukkan bahwa pemberian berbagai taraf konsentrasi NAA tidak mampu meningkatkan jumlah daun dikarenakan jumlah daun lebih dipengaruhi oleh sitokinin. 
Menurut Skoric et al. (2012) konsentrasi NAA yang semakin tinggi akan menghambat pembelahan sel tetapi berfungsi dalam pembesaran sel, sehingga jumlah daun yang dihasilkan sedikit.

Analisis sidik ragam juga menunjukkan bahwa tidak terdapat interaksi antara kombinasi NAA dan BAP terhadap parameter jumlah daun. Hal tersebut dikarenakan kombinasi konsentrasi antara NAA dan BAP belum mencapai keseimbanagn yang optimal, sehingga belum mampu menghasilkan jumlah daun yang optimal. Menurut Karjadi dan Buchory (2007) penambahan sitokin dan auksin dalam perbanyakan tanaman secara kultur jaringan terbukti berperan dalam menunjang pertumbuhan jaringan apabila dalam konsentrasi yang tepat. Jumlah daun pada perlakuan $1,5 \mathrm{mg} / \mathrm{l} \mathrm{NAA}+0,9 \mathrm{mg} / \mathrm{BAP}$ memiliki jumlah daun yang lebih banyak dari perlakuan lainnya yaitu $8,00 \pm 1,47$ daun. Jumlah daun tersebut lebih rendah dari penelitian sebelumnya Hoesen (2009) multiplikasi Lilium sp. selama 6 minggu jumlah daun terbanyak yaitu pada perlakuan $0 \mathrm{mg} / \mathrm{l} \mathrm{NAA}+1 \mathrm{mg} / \mathrm{l} \mathrm{BAP}$ dengan jumlah 10,67 daun.

\section{Jumlah Akar}

Data jumlah akar (Tabel 5) menunjukkan bahwa tidak semua bulblet yang diinisiasi membentuk akar.

Tabel 5. Jumlah Akar Berdasarkan Kombinasi NAA dan BAP

\begin{tabular}{|c|c|c|c|c|c|}
\hline \multirow{2}{*}{$\mathrm{NAA}(\mathrm{mg} / \mathrm{l})$} & \multicolumn{4}{|c|}{$\mathrm{BAP}(\mathrm{mg} / \mathrm{l})$} & \multirow{2}{*}{ Rata-rata } \\
\hline & 0 & 0,3 & 0,6 & 0,9 & \\
\hline 0 & 2,00 & 0,00 & 0,00 & 0,00 & 2,00 \\
\hline 0,75 & 5,33 & 2,00 & 2,00 & 0,00 & 3,11 \\
\hline 1,50 & 3,50 & 1,00 & 0,00 & 0,00 & 2,25 \\
\hline 2,25 & 6,50 & 0,00 & 0,00 & 0,00 & 6,50 \\
\hline Rata-rata & 4,33 & 1,50 & 2,00 & 0,00 & \\
\hline
\end{tabular}

Akar paling banyak yaitu pada perlakuan tunggal NAA tanpa pemberian BAP. Menurut Skoric et al. (2012) pembentukan akar pada Lilium martagon dirangsang dengan penambahan NAA, sedangkan penambahan BAP yang terlalu tinggi akan menghambat pembentukan akar. Akar pada perlakuan 2,25 mg/l NAA + $0 \mathrm{mg} / \mathrm{l}$
BAP memiliki jumlah akar terbanyak dari perlakuan lainnya yaitu 6,50 akar. Hal tersebut menunjukkan bahwa konsentrasi 2,25 mg/l NAA merupakan konsentrasi yang terbaik untuk jumlah akar pada penelitian ini. Jumlah akar pada penelitian ini lebih rendah dari penelitian Han et al. (2004) pada multiplikasi Lilium longiflorum 'Georgia' 
dimana dari berbagai kombinasi konsentrasi antara NAA dan BAP hanya perlakuan tunggal NAA yang mampu membentuk akar dengan jumlah akar paling banyak yaitu 8,5 akar pada perlakuan tunggal 0,5 mg/l NAA.

Akar yang terbentuk tidak hanya pada perlakuan tanpa BAP akan tetapi pada perlakuan dengan penambahan BAP ada beberapa eksplan yang membentuk akar. Hal tersebut diduga bahwa kandungan auksin endogen pada eksplan sudah cukup tinggi sehingga dengan penambahan BAP akar tetap dapat terinduksi, sedangkan pada eksplan yang tidak mampu memunculkan akar diduga karena kandungan auksin endogen dalam eksplan sedikit dan penambahan NAA dan BAP belum mampu mendorong terbentuknya akar. Menurut Karjadi dan Buchory (2007) eksplan tidak mampu membentuk akar karena pertumbuhan akar dihambat oleh adanya sitokinin yang terlalu tinggi dan juga

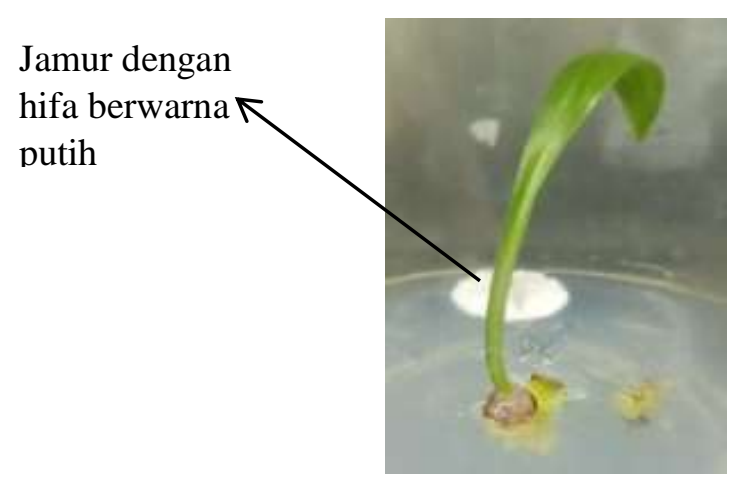

penghambatan tersebut dapat disebabkan oleh terbentuknya etilen. Kandungan etilen yang terlalu tinggi tersebut dapat menghambat aktivitas auksin dalam pemanjangan sel, sehingga akar tidak akan terinduksi.

\section{Persentase Kontaminasi}

Data persentase kontaminasi (tabel 6) menunjukkan bahwa dari 16 perlakuan dan 5 ulangan hanya beberapa perlakuan yang terkontaminasi, sehingga persentase kontaminasinya yaitu sebesar 7,5\% . Perlakuan yang terkontaminasi tersebut yaitu perlakuan A0B0, A0B3, A1B0, A2B1, A3B0, dan A3B1 dengan jumlah media yang terkontaminasi yaitu masing-masing perlakuan 1 . Kontaminasi tersebut disebabkan oleh munculnya jamur pada media yang dicirikan dengan adanya hifa berwarna putih dan abu-abu seperti benang dan membentuk koloni (llustrasi 2).

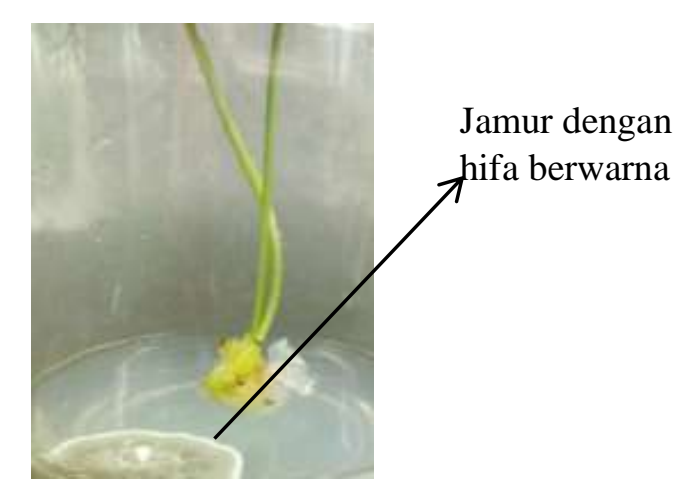

Ilustrasi 2. Media yang Terkontaminasi jamur 
Hal tersebut sesuai dengan pendapat Admojo dan Prasetyo (2016) yang menyatakan bahwa kontaminasi oleh jamur dicirikan dengan munculnya hifa jamur pada media dan biasanya terdapat garis-garis (seperti benang) yang berwarna putih, abuabu, dan kekuningan. Kontaminasi jamur tersbeut terlihat pada 2-4 minggu setelah inisiasi. Kontaminasi jamur tersebut hanya terdapat pada pinggir media dan tidak sampai ke eksplan, sehingga walaupun terdapat jamur dipinggir media pertumbuhan eksplan tidak terhambat. Munculnya kontaminasi jamur pada media dapat disebabkan beberapa faktor, antara lain kurang sterilnya peralatan yang digunakan sehingga jamur dapat terbawa saat proses penanaman. Kontaminasi juga dapat disebabkan oleh kurang memadainya lingkungan kultur, sehingga memungkinkan jamur untuk berkembangbiak dalam media kultur.

Tabel 6. Persentase Kontaminasi

\begin{tabular}{|c|c|c|c|c|}
\hline Perlakuan & $\begin{array}{l}\text { Jumlah } \\
\text { Ulangan }\end{array}$ & $\begin{array}{c}\text { Jumlah } \\
\text { Kontaminasi }\end{array}$ & $\begin{array}{c}\text { Persentase } \\
\text { Kontaminasi (\%) }\end{array}$ & Keterangan \\
\hline AOBO & 5 & 1 & 20 & \multirow{9}{*}{$\begin{array}{l}\text { Jamur } \\
\text { Jamur }\end{array}$} \\
\hline A0B1 & 5 & 0 & 0 & \\
\hline A0B2 & 5 & 0 & 0 & \\
\hline A0B3 & 5 & 1 & 20 & \\
\hline A1B0 & 5 & 1 & 20 & \\
\hline A1B1 & 5 & 0 & 0 & \\
\hline A1B2 & 5 & 0 & 0 & \\
\hline A1B3 & 5 & 0 & 0 & \\
\hline A2B0 & 5 & 0 & 0 & \\
\hline $\mathrm{A} 2 \mathrm{~B} 1$ & 5 & 1 & 20 & \multirow{3}{*}{ Jamur } \\
\hline A2B2 & 5 & 0 & 0 & \\
\hline A2B3 & 5 & 0 & 0 & \\
\hline A3B0 & 5 & 1 & 20 & \multirow{5}{*}{$\begin{array}{l}\text { Jamur } \\
\text { Jamur }\end{array}$} \\
\hline A3B1 & 5 & 1 & 20 & \\
\hline A3B2 & 5 & 0 & 0 & \\
\hline A3B3 & 5 & 0 & 0 & \\
\hline Jumlah & 80 & 6 & 7,5 & \\
\hline
\end{tabular}

Keterangan:

$\begin{array}{llllllll}\text { A0 } & : 0 \mathrm{mg} / \mathrm{l} & \text { A1 } & : 0,75 \mathrm{mg} / \mathrm{l} & \text { A2 } & : 1,5 \mathrm{mg} / \mathrm{l} & \text { A3 } & : 2,25 \mathrm{mg} / \mathrm{l} \\ \text { B0 } & : 0 \mathrm{mg} / \mathrm{l} & \text { B1 } & : 0,3 \mathrm{mg} / \mathrm{l} & \text { B2 } & : 0,6 \mathrm{mg} / \mathrm{l} & \text { B3 } & : 0,9 \mathrm{mg} / \mathrm{l}\end{array}$


Hal tersebut sesuai dengan pendapat Karjadi dan Buchory (2007) bahwa kontaminasi secara internal bersumber dari eksplan dan secara eksternal bersumber dari lingkungan kultur yang kurang memadai. Elfiani dan Jakoni (2015) menambahkan bahwa kontaminasi dapat berasal dari eksplan, mikroorganisme dari luar, botol atau perlatan yang kurang steril, lingkungan kerja, ruang kultur serta kecerobohan dalam pelaksanaan.

\section{KESIMPULAN}

Simpulan yang diperoleh yaitu perlakuan 0,3 mg/l BAP + 0,75 mg/l NAA merupakan perlakuan yang terbaik, dengan jumlah tunas $1,25 \pm 0,25$, tinggi planlet 6,88 $\pm 0,55 \mathrm{~cm}$, jumlah daun $5,00 \pm 1,73$, jumlah akar 2, dan tidak terkontaminasi jamur. Saran yang diberikan untuk perlakuan selanjutnya yaitu ditambahkan konsentrasi BAP dan konsentrasi NAA diturunkan sehingga dapat mengetahui konsentrasi kombinasi NAA dan BAP yang sesuai untuk pertumbuhan planlet. Selain itu sebaiknya planlet dipindahkan ke media perakaran agar semua planlet mampu membentuk akar.

\section{DAFTAR PUSTAKA}

Admojo, L., dan N.E. Prasetyo. (2016). Pengaruh sterilan terhadap tingkat kontaminasi pada kultur petiol dan midrib daun tanaman karet (Hevea brasiliensis Muell arg.) klon PB 330.
Jurnal Penelitian Karet, 34 (2), 151 164.

Aslam, F., S. NAz, A. Tariq, S. Ilyas dan K. Shahzadi. (2013). Rapid multiplication ornamental bulbous plants of Lilium orientals and Lilium longiflorum. Journal of Bot, 45 (6), 2051-2055.

Bakhshaie, M., S. Khosravi, P. Azadi, dan H. Bagheri. (2016). Biotechnologi advance in Lilium . Journal of Plant Cell Reports, 35 (9), 1799-1826.

Elfiani dan Jakoni. (2015). Sterilisasi eksplan dan sub kultur anggrek, sirih merah, dan krisan pada perbanyakan tanaman secara in vitro. Jurnal Dinamika Pertanian, 30 (2), 117-124.

Han, B. H., H. J. Yu., B. W. Yae dan K. Y. Peak. (2004). In vitro micropropagation of Lilium longiflorum 'Georgia' by shoot formation as influenced by addition of liquid medium. Journal of Scientia Horticulturae, 103, 39-49.

Hoesen, D. S. H. (2009). Pembentukan tunas Lilium sp. secara ex vitro dan in vitro. Jurnal Teknologi Lingkungan, 10 (2), 183-193.

Karjadi, A. K., dan A. Buchory. (2007). Pengaruh komposisi media dasar, penambahab BAP, dan pikloram terhadap induksi tunas bawang merah. Jurnal Hortikultura. 18 (1), 1 9.

Lawalata, I.J. (2011). Pemberian beberapa kombinasi zpt terhadap regenerasi tanaman Gloxinia (Siningia speciosa) dari eksplan batang dan daun secara in vitro. Jurnal Exp.Life Sci, 1 (2), 8387.

Mir, J.I., Ahmed, M. A. Sheikh, R. Rashid, dan S. H. Wani. (2012). In vitro propagation of Lilium (Lilium longiflorum), 82 (5), 65-68. 
Pandey, R. K., A. K. Singh, dan M. Sharma. (2009). In vitro propagation of Lilium . International Journal, 1 (2), 26-28.

Rosyidah, M., E. Ratnasari, Y.S. Rahayu. (2014). Induksi kalus daun melati (Jasminum sambac) dengan penambahan berbagai konsentrasi 2,4-D dan BAP pada media MS secara in vitro. Jurnal Lentera Bio. 3 (3), 147153.

Rufaida, A., Waeniaty, Muslimin, dan I. N. Suwastika. (2013). Organogenesis tanaman bawang merah (Allium ascalonicum L.) lokal palu secara in vitro pada medium ms dengan penambahan IAA dan BAP. Journal of Natural Science, 2 (2), 1-7.

Skoric, S., J. Savic, B. Siler, A. Sabovilevic, S. Todorovic, dan D. Grubisic. (2012). Efficient one-step tissue culture protocol for propagation of endemic plant, Lilium martagon var. cattaniae Vis. African Journal of Biotechnology, 11 (8), 1862-1867.

Sun, L., Z. Zhou, dan K. Cheng. (2013). Plant micropropagation from in vitro cultured bulb scales of Lilium lancifolum. Journal of Life Science, 10 (2), 26892692.

Tajuddin, R., i. N. Suwastika, dan Muslimin. (2012). Organogenesis tanaman anggrek hijau (Vitis vinifera L.) pada medium ms dengan penambahan IAA (indole acetid acid) dan berbagai konsentrasi BAP (benzil amino purin). Journal of Natural Science, 1 (1), 6373.

Wulandari, C., W. E. Murdiono, dan N. Barunawati. (2018). Pengaruh konsentrasi sitokinin dan auksi terhadap pertumbuhan planlet
Anthurium plowmanii Croat. Jurnal Produksi Tanaman, 6 (10), 2531-2538. Yuniati, F., S. Haryanti, dan E. Prihastanti. (2018). Pengaruh hormon dan ukuran eksplan terhadap pertumbuhan mata tunas tanaman pisang (Musa paradisiaca var. Raja Bulu) secara in vitro. Buletin Agronomi dan Fisiologi, 3 (1), 20-28. 